ESJ Social Sciences

\title{
The Impact of a Health-run on Remittances and Financial Inclusion
}

\author{
Sunday Agbor Mbu \\ Department of Economics and Management Sciences, \\ University of Buea, Cameroon \\ Maurice Ayuketang Nso \\ Higher Institute of Commerce and Management, \\ The University of Bamenda, Cameroon
}

Doi:10.19044/esj.2021.v17n23p229

Submitted: 15 June 2021

Accepted: 01 July 2021

Published: 31 July 2021

\author{
Copyright 2021 Author(s) \\ Under Creative Commons BY-NC-ND \\ 4.0 OPEN ACCESS
}

\section{Cite As:}

Mbu S.A. \& Nso M.A. (2021). The Impact of a Health-run on Remittances and Financial Inclusion. European Scientific Journal, ESJ, 17(23), 229.

https://doi.org/10.19044/esj.2021.v17n23p229

\begin{abstract}
The study examines the impact of health runs or crises on financial remittances and inclusion. Data were collected through a survey questionnaire administered to a sample of 60 respondents made up of financial services employees and users of financial services, irrespective of their age and years of trade experience. Results show that remittances and financial inclusion levels should be affected adversely due to the coronavirus ( COVID-19) health run. The magnitude of the negative effect of a health crisis on financial remittances and inclusion as measured by the correlation matrix is strong, but comparatively the same for the assessed variables. Our findings reveal that a severe global health crisis would force an exponential decline in remittances and financial inclusion. Findings further reveal that there exists no relationship between financial remittances and financial inclusion under a health crisis. The study here recommends measures policymakers can use to boast financial flows and inclusion during a period of a severe global health crisis.
\end{abstract}

Keywords : Financial Inclusion, Financial Institutions, Financial Sector, Health-run, Remittances, Users of Financial Services 


\section{Introduction}

The effects of either health or financial crisis on businesses, economic sectors, and the financial system might be broad to handle here, but the specific effect of a global run-on health on financial flows and inclusion needs to be given the distinct attention it deserves. This is worthy of consideration, especially at a time like this when there are mounting concerns of how riskexposed all economic sectors are as a result of the Coronavirus (COVID-19) pandemic. Not limiting to that, crisis-prone areas are likely to have stringent financial and monetary policies to overcome the adverse effects. This statement agrees with the study of Bech, Gambacorta, and Kharroubi (2012), indicating that monetary policy is less effective in a financial crisis; while Antohi and Cojocaru (2015) posit that each country or state confronts itself with different situations in the health issue. If this could be experienced during a financial crisis, then, it is likely to be experienced during a global health crisis. This implies that a more burden on stricter financial and monetary policies is required during a global health crisis. These policies in a way could impact financial flows and inclusion within the local and the international banking systems. Further, a health crisis causes shocks to the economy and equally slows down household and business activities in the affected areas. This could further have ripple effects on remittances and financial inclusion at the level of commercial banks and banking firms. In case remittances and financial inclusion are affected by a health crisis and of what impact could it? In case of any effect commercial banks, monetary authorities, and policymakers need to overcome the impact by making appropriate policies and the financial industry resilient to withstand business and economic shocks emanating from a run-on health. Remittances in this study include both inbound and outbound fund transfers. Inbound remittances include local fund transfer of the same currency, in the same country and monetary zone. On the other hand, outbound remittances include international fund transfers requiring the exchange of a local currency with a foreign currency in a different country and monetary zone. On its part, financial inclusion goes beyond having bank branches to getting households and businesses to open accounts with commercial banks and other financial institutions. Ficawoyi, Gyan and Hem (2020) investigated the relationship between remittances and financial development and found a significant positive long-run relationship. Attached to financial development is financial inclusion, financial institutions (with commercial banks being central in them), households and businesses (Johnson, 2020), and all these are affected by economic and environmental shocks. Health crises in a way represent a form of environmental shock that can affect both remittances and financial inclusion. The attention of this study is on commercial banks, financial services employees, and business owners or workers as users of financial services, since they form the pool of respondents 
to the study's questionnaire. This study, therefore, examines the impact of a run-on health on financial remittances and inclusion at the level of commercial banks.

\subsection{Structure of the Study}

The study whose main objective is to assess the implications of a health run on remittances and financial inclusion is structured as follows: the introduction is immediately followed by a review of existing and relevant literature on the Coronavirus outbreak and remittance as well as financial inclusion concepts. The third section plays host to the methodology that was employed to carry out this study. The results are discussed in the fourth section, while the conclusion and recommendation are contained in the fifth and last section of the study.

\section{Literature Review}

This section covers details on the health crisis in particular the Coronavirus (COVID - 19) outbreak and the concept of remittance and financial inclusion.

\subsection{Health Crisis and the Coronavirus (COVID-19) Outbreak}

Health is defined by The World Health Organisation (WHO) as the state of physical, mental, and psychological well being of a person. A health crisis such as the ongoing COVID-19 which the WHO classified as a global pandemic in March 2020 has touched not just the physical and the psychological wellbeing of individuals, but also businesses and economies of nations of the world. There exists a long history of health crises documented in health economics textbooks and research articles for readers' consumption. In this study, our interest is on the link between health run and financial flows and inclusion assessment. The advent of the COVID-19 pandemic has changed how individuals, businesses, and economies live, operate, and function daily. Just these shifts in behavioural patterns of economic sectors could further lead to serious changes not just in the economy, but also in financial and banking need factors such as financial remittances and inclusion of household and business units in the banking sector during periods of a health crisis.

The COVID-19 pandemic and related adverse confidence effects are having severe negative impacts on global economic activity and pose an imminent threat to financial stability, emerging market and developing economies (EMDEs) are facing a sharp sudden stop in capital inflows, with the attendant high risk of currency crises, remarked Harjes et al (n.d.) in their work titled Monetary and Financial Policy Responses for Emerging Market and Developing Economies that offers an overview of appropriate central bank 
policy responses to the severe economic and financial impact of the Covid-19 pandemic. They further affirm that the COVID-19 outbreak is a health shock that is exogenous to the economy and the financial system. According to them, countries will need to deal with domestic disruptions, increased health spending, and other wide-ranging aspects of the shock. These actions will only expose the validity of a health crisis.

\subsection{Remittances and Financial Inclusion}

Financial and banking services go beyond remittances and financial inclusion to include the safe keeping of values, processing payments, offering investment advice and loans to clients. It is an open and affirmed fact that not all economic sectors can process banking transactions if there are no bank accounts accessible (Nso, 2019). Thus, financial inclusion is paramount with or without a health crisis. On the other hand, while there exist non-banking account means of having remittances processed, prudential and compliant banking requirements encourage banking institutions and financial houses to process payments with bank accounts accessed to minimise transaction, operations, and business risks and costs. Consequently, during a global crisis such as the COVID-19 pandemic where banks, households, businesses, and economic sectors are exposed to all sorts of risks and costs, the level of remittances is likely to be impacted.

Remittance represents the financial flows from and within the banking institutions. Remittance represents a vital economic lifeline for both struggling and non-struggling households and businesses. These remittances improve living standards in countless ways and help to make vulnerable communities resilient to shocks like economic downturns, natural and man-made disasters (Thompson, 2014). Remittances serve as social insurance against political, economic, and health crises and a kind of livelihood diversification plan to all beneficiaries.

Financial inclusion is the availability and equal opportunity to access financial services in the banking sector. Nashipu et al (2020) agree that financial inclusion is important in reducing inequality of opportunities among households. In a similar study, Demirguc-Kunt et al (2008) affirms the wide acceptance of financial inclusion as a pro-growth tool and its important role in reducing poverty globally. Financial inclusion comprises affordable access to financial services, availability and sharing of financial information, availability of banking offices and branches and access to loans. The end and inclusive aspect of financial inclusion is that the potential user of financial services acquired and consumed the services offered by banks and financial institutions, of which remittances are important services offered by them. Thus, a person is financially inclusive when he or she consumes the services offered by a financial services provider, firm, company, or bank. 
As observed in the aforementioned deliberations, it is imperative to assess the possible association between remittance and financial inclusion under the condition of a prevalent global health crisis. This is important because, under normal economic, environmental, business and health conditions, one would at least expect remittances to be driven by financial inclusion.

\section{Methodology for the Study}

This section explains the research design, sampling technique, the framework for the study, the research tools and the data analysis methods used for the study in order to come out with the study results.

\subsection{Research Design}

The study employed both qualitative and quantitative research approaches. In the qualitative aspect, questionnaires were used to collect the much-needed primary data to complement the quantitative data to test the hypotheses inferentially. The quantitative research technique was used in analysing the research data collected on the variables under examination. A quantitative research technique is being used to assess the objective of the study.

\subsection{Sampling Technique}

Three sampling techniques were employed to collect data for this study. They include: stratified, purposive, and random sampling techniques. A stratified sampling technique was used to first classify respondents into two major classes. The two major classes are the financial sector employees (commercial banks employees) irrespective of sex, age, and working experience, and users of financial services such as business people, owners and/or workers; made up of both females and males, irrespective of age and years of business experience.

Secondly, purposive sampling was conveniently applied on each stratum to ensure that the final respondents have a basic understanding of the variables under assessment. This helped to ensure objectivity in the opinions of the final respondents. The variables under assessment included: run on health (health crisis), financial remittances, and financial inclusion.

Then, finally, a random sampling technique was applied to select the final respondents arbitrarily to respond to the study's questionnaires. This further helped to minimise and avoid bias in the opinions of the respondents.

Employing these sampling techniques was not easy to go by, as the attention of all the respondents in the strata were in high demand and potential respondents whose attention could not be assured were left out of the final sample that provided their responses to the questions. However, the techniques are worthy of consideration as they ensured that only the knowledgeable, 
convenient and most willing respondents submitted their responses for examination in the study. This means that the final data obtained from the respondents could be viewed as reliable and worthy of trust to meet and satisfy the objective of the study.

Based on Field (2013), Hosmer, Lemeshow, and Sturdivant (2013), and Leblanc and Fitzgerald (2000), the sample size of 60 respondents suffices for the study and it satisfies the recommended basic requirement for such a study. Field (2013) states that larger samples are needed for linear regression because maximum coefficients with a minimum of 50 cases per predictor are recommended. On their part, Hosmer, Lemeshow, and Sturdivant (2013) suggest a minimum sample of 10 observations per independent variable in the model, but caution that 20 observations per variable should be sought if possible. In contrast, Leblanc and Fitzgerald (2000) suggest a minimum of 30 observations per independent variable.

\subsection{Research Framework Used for the Study}

The study identified three (3) key variables for examining the impact of a health crisis on remittances and financial inclusion. The variables under study included: Run-on-Health, Remittances, and Financial Inclusion. Healthrun produced two outcomes; a Yes or a No. This dichotomous character of the data collected legitimated the health-run variable to be best considered as the dependent variable under the binary logistic regression technique. Applying the same technique for evaluation; Remittance and Financial Inclusion not being measured by a nominal scale, best suited the independent variables to set up a binary logistic regression equation framework for the data analysis process.

This means that a connecting relationship between health-run, remittances, and financial inclusion could be expressed using the direct and indirect effect model.

The direct effect model is defined by:

Where;

$$
\mathrm{AHR}=\mathrm{f}(\mathrm{RT}, \mathrm{FI})
$$

AHR is A Run on Health, RT is Remittances and FI is Financial Inclusion. The above equation (1) shows the direct connecting relationships between a Run on Health, Remittances and Financial Inclusion.

The indirect effect model is defined by:

$$
\mathrm{AHR}=\mathrm{f}(\mathrm{RT},(\mathrm{FI}))
$$

This equation (2) shows that remittances are not only directly affected by runon health, but also by financial inclusion.

Typically, the binomial logistic regression research equation is given by; $\log (\mathrm{p} / 1-\mathrm{p})=\mathrm{bo}+\mathrm{b} 1 * \mathrm{x} 1+\mathrm{b} 2 * \mathrm{x} 2$ 
where $\mathrm{p}$ is the probability of being in honours composition, expressed in terms of the independent variables. The bs are the values for the logistic regression equation for predicting the dependent variable from the independent variables. They are in log-odds units. Similar to OLS regression as shown in the prediction equation.

By substituting the variables under study in the typical binomial logistic equation, the direct effect econometric model is expressed as:

$$
\mathrm{ARH}=\mathrm{bo}+\mathrm{b} 1 \times \mathrm{RT}+\mathrm{b} 2 \mathrm{xFI}
$$

and the indirect effect econometric model is expressed as:

$$
\begin{aligned}
\mathrm{ARH} & =\mathrm{bo}+\mathrm{b} 1 \times \mathrm{RT}(\mathrm{b} 2 \times \mathrm{FIb}) \\
\mathrm{ARH} & =\mathrm{RT}(\mathrm{FI})
\end{aligned}
$$

This indirect effect econometric model could best be assessed using a correlation coefficient technique arranged in a matrix with ARH (A Run on Health) as the constant.

\subsection{Research Technique Tool Used for the Study}

The study made use of binary logistics techniques in analysing the research data between the dependent variable and the two independent variables for the examination of the direct effect. In addition, a correlation matrix technique was used to evaluate the indirect effect within the variables in the study.

Logistic regression is used to determine the impact of multiple independent variables presented simultaneously to predict the membership of one or the other of the two dependent variable categories. The binary logistic regression also provides the relationships and strengths among the variables. Logistic regression does not assume a linear relationship between the dependent and independent variables. Meanwhile, correlation coefficients range from -1 to 1 ; with -1 indicating a perfectly negative linear correlation between two variables, 0 indicating no linear correlation between two variables, and 1 indicating a perfect positive linear correlation between two variables.

\subsection{Data Analysis}

The research data were coded and data entry recorded in IBM SPSS 24 for data analysis Burns \& Burns (2008). The analysed outputs were obtained and presented for interpretation.

George and Mallery (2003) classify Cronbach's alpha reliability coefficient as; $>.9$ excellent, $>.8$ good, $>.7$ acceptable, $>.6$ questionable, $>.5$ poor and $<.5$ unacceptable. In general, Cronbach's alpha reliability coefficient normally ranges between 0 and 1 , and the closer the coefficient is to 1.0, the greater the internal consistency of the items (variables) in the scale. Hulland (1999) and Cronbach (1951) recommend construct reliability score of at least 
0.7 to ensure that items in a construct are reliable and are internally consistent without error in measurement and evaluation.

For the test of validity, a bivariate Pearson correlation generates a score ranging between -1 and 1 and a 2 -tailed test is used to generate a p-value which is compared to know if it is less than the critical p-value of 0.05 for a correlation score that is significant. Carmines and Zeller (1979) state that convergent validity is the degree of agreement between two or more indicators of the same construct. Convergent validity measures the extent to which a set of items on a questionnaire reflect the theoretical unobserved construct they are designed to measure. Convergent validity occurs if all the assessed factors loadings are greater than 0.05 .

Skewness and kurtosis were used to test the distribution normality. Byrne (2013) recommends that normally distributed data if skewness for the various items ranges between -2 to 2 , while kurtosis score ranges between -7 and 7. On the same subject, Bentler (1990) suggests a more stringent criterion of 1.96 for both skewness and kurtosis.

In logistic regression, hypotheses are of interest: the null hypothesis, which is when all the coefficients in the regression equation take the value zero, and the alternate hypothesis, which is when the model currently under consideration is accurate and differs significantly from the null or zero, i.e. gives significantly better than the chance or random prediction level of the null hypothesis (UCLA - Institute for Digital Research and Education Statistical Consulting, 2021). Logistic regression does not assume a linear relationship between the dependent and independent variables. On the other hand, to assess the indirect effect within the variables, a correlation technique was used. Correlation coefficients range from -1 to 1 ; with -1 indicating a perfectly negative linear correlation between two variables, 0 indicating no linear correlation between two variables, and 1 indicating a perfect positive linear correlation between two variables.

\section{Results}

The study results consist of the descriptive and inferential aspects of the study.

\subsection{Descriptive Results \\ i) Respondents' Background}

The survey sample consisted of 60 respondents. The profile of the respondents included people with knowledge on what a health crisis is and banking services. They were selected from a group of financial services employees (banks employees) and financial services users such as business operators and family members as shown in table 1 below. Our choice of respondents helped to minimise bias and ensure the reliability of the data collected. 
Table 1: Respondents' Background

\begin{tabular}{|c|c|c|c|c|c|}
\hline \multicolumn{2}{|c|}{ Respondents' Background } & \multirow{2}{*}{$\begin{array}{l}\text { Frequency } \\
30\end{array}$} & \multirow{2}{*}{$\begin{array}{l}\text { Percentage } \\
50.0\end{array}$} & \multirow{2}{*}{$\begin{array}{l}\text { Valid } \\
\text { Percentage } \\
50.0\end{array}$} & \multirow{2}{*}{$\begin{array}{l}\text { Cumulative } \\
\text { Percentage }\end{array}$} \\
\hline \multirow{3}{*}{ Valid } & $\begin{array}{l}\text { Financial Sector } \\
\text { employee }\end{array}$ & & & & \\
\hline & $\begin{array}{l}\text { User of Financial } \\
\text { Services }\end{array}$ & 30 & 50.0 & 50.0 & 100.0 \\
\hline & Total & 60 & 100.0 & 100.0 & \\
\hline
\end{tabular}

\section{ii) Prevalence of a Health Crisis}

Of the 60 respondents who submitted their responses to the question 'Does the outbreak of the coronavirus (COVID-19) disease cause a (runon) health crisis?' $71.7 \%$ of them believed that the outbreak of the coronavirus (COVID -19) disease has caused a run-on health to be termed a health crisis as shown in table 2 that follows.

Table 2: Prevalence of a Health Crisis

\begin{tabular}{|lc|l|l|l|l|}
\hline $\begin{array}{l}\text { Prevalence of a } \\
\text { health Crisis }\end{array}$ & $\begin{array}{l}\text { Frequenc } \\
\mathrm{y}\end{array}$ & $\begin{array}{l}\text { Percent } \\
\text { age }\end{array}$ & $\begin{array}{l}\text { Valid } \\
\text { Percentage }\end{array}$ & $\begin{array}{l}\text { Cumulative } \\
\text { Percentage }\end{array}$ \\
\hline \multirow{4}{*}{ Vali } & Yes & 43 & 71.7 & 71.7 & 71.7 \\
d No & 17 & 28.3 & 28.3 & 100.0 \\
& Tota & 60 & 100.0 & 100.0 & \\
& 1 & & & & \\
\hline
\end{tabular}

\section{iii) Reliability Test}

The measuring reliability test in table 3 below shows that the data collected for the variable Run-on Health is statistically reliable. This is important in that it reaffirms that the $71.7 \%$ of the respondents who indicated that the current run-on health is sufficient to be termed a health crisis is statistically reliable to prompt the continuation of the study. Though the negative Cronbach's Alpha for the other variables do violate the reliability model assumption. It is still good to proceed with the study to test its hypotheses. The negative value is a result of the presence of a negative average covariance among items (variables).

Table 3: Cronbach's Alpha Test for measuring Reliability

\begin{tabular}{|l|l|}
\hline Variables & Cronbach's Alpha \\
\hline Run-on Health & .967 \\
Remittances & -2.474 \\
Financial Inclusion & -2.896 \\
\hline
\end{tabular}




\section{iv) Bivariate test for Validity}

Based on the results of the bivariate test for the validity of variables under examination shown on table 4 below, it is evident that all the variables are distributive, convergent, and constructively valid. This means that the method of measurement (binary logistics) matches the construct equation under examination.

Table 4: Bivariate Test for Validity of Variables under examination

\begin{tabular}{|ll|l|l|l|}
\hline Variables under examination & RunonHealth & Remittances & Financial Inclusion \\
\hline \multirow{4}{*}{ Run-on Health } & Pearson Correlation & 1 & $-.859^{* *}$ & $-.853^{* *}$ \\
& Sig. (2-tailed) & & .000 & .000 \\
& $\mathrm{~N}$ & 60 & 60 & 60 \\
\multirow{5}{*}{ Remittances } & Pearson Correlation & $-.859^{* *}$ & 1 & $.939^{* *}$ \\
& Sig. (2-tailed) & .000 & & .000 \\
& $\mathrm{~N}$ & 60 & 60 & 60 \\
\multirow{2}{*}{ Financial Inclusion } & Pearson Correlation & $-.853^{* *}$ & $.939^{* *}$ & 1 \\
& Sig. (2-tailed) & .000 & .000 & \\
& $\mathrm{~N}$ & 60 & 60 & 60 \\
\hline
\end{tabular}

**. Correlation is significant at the 0.01 level (2-tailed).

\section{v) Test for Distribution Normality}

Based on the normality test in table 5 below, results show that all the variables in the model equation are normally distributed.

Table 5: Test for Distribution Normality

\begin{tabular}{|l|l|l|l|l|}
\hline \multirow{2}{*}{ Variables } & \multicolumn{3}{l|}{ Skewness } & Kurtosis \\
\cline { 2 - 5 } & Statistic & Std. Error & Statistic & Std. Error \\
\hline Run-on Health & .986 & .309 & -1.063 & .608 \\
Remittances & -1.005 & .309 & .287 & .608 \\
Financial Inclusion & -.744 & .309 & -.465 & .608 \\
FSUFS & .000 & .309 & -2.070 & .608 \\
Valid N (listwise) & & & & \\
\hline
\end{tabular}

\subsection{Inferential Results}

\subsubsection{The Direct Effect Results}

The direct effect econometric model expressed as ARH $=\mathrm{bo}+\mathrm{b} 1 \mathrm{xRT}$ $+b 2 x F I$ was assessed using a binary logistic and the results of the analysis are shown in tables 6 and 10 .

With the Wald chi-square to test the appropriateness of the experienced run-on health to qualify it as a health crisis or not. In case of no crisis (the null hypothesis), the constant will be equal to 0 . This hypothesis is rejected because the p-value .001 is smaller than the critical p-value of .05. It is concluded that the constant is not 0 . Hence, the $71.7 \%$ of respondents who affirmed the current run-on health to be termed a health crisis are just. Although this finding 
is not usually interesting to researchers, in this study, it is important to qualify that the run-on health is appropriately termed a health crisis and this is the case with the Coronavirus ( COVID-19) disease which has been termed a global health crisis or pandemic by The World Health Organisation (WHO).

Table 6: Test for Variables in the Equation

\begin{tabular}{|ll|l|l|l|l|l|l|}
\hline & & B & S.E. & Wald & df & Sig. & $\operatorname{Exp(B)}$ \\
\hline Step 0 & Constant & -.928 & .286 & 10.492 & 1 & .001 & .395 \\
\hline
\end{tabular}

The overall Model coefficients are statistically significant as shown on table 7 with p-values of .000 less than the critical p-value of .05 .

Table 7: Omnibus Tests of Model Coefficients

\begin{tabular}{|ll|l|l|l|}
\hline & & Chi-square & df & Sig. \\
\hline \multirow{4}{*}{ Step 1 } & Step & 67.030 & 2 & .000 \\
& Block & 67.030 & 2 & .000 \\
& Model & 67.030 & 2 & .000 \\
\hline
\end{tabular}

According to the Cox \& Snell R Square and Nagelkerke R Square on table 8 with both results being greater than 0.5 critical value, the model is statistically significant (or good) for a binary logistic analysis to examine the variables under study.

Table 8: Model Summary

\begin{tabular}{|l|l|l|l|}
\hline Step & $\begin{array}{l}-2 \quad \text { Log } \\
\text { likelihood }\end{array}$ & $\begin{array}{l}\text { Cox \& Snell R } \\
\text { Square }\end{array}$ & $\begin{array}{l}\text { Nagelkerke R } \\
\text { Square }\end{array}$ \\
\hline 1 & $4.499^{\mathrm{a}}$ & .673 & .966 \\
\hline
\end{tabular}

a. Estimation terminated at iteration number 20 because maximum iterations have been reached. Final solution cannot be found.

The Hosmer and Lemeshow test on table 9 shows that the binary logistic model deployed for this study passed the goodness of fit test. This means that the constructed model is suitable for the study to apply binary logistic analysis.

Table 9: Hosmer and Lemeshow Test

\begin{tabular}{|l|l|l|l|}
\hline Step & Chi-square & df & Sig. \\
\hline 1 & .000 & 5 & 1.000 \\
\hline
\end{tabular}

On the results of the direct effect, reading from table 10 on the variables in the Equation, the logistics regression equation is given as: $\log (\mathrm{p} / 1-\mathrm{p})=108.092-19.275^{*}$ Remittances $-16.389 *$ FinancialInclusion (6)

But in the full model analysis output shown in the appendix section, $\mathrm{p}=98.3 \%$ It means; 
$\log (\mathrm{p} / 1-\mathrm{p})=\log (0.983 / 1-0.983)=\log (0.983 / 0.017)=\log 57.8235$

Thus, the logistics equation becomes;

$\log 57.8235=108.092-19.275 *$ Remittances $-16.389 *$ FinancialInclusion (7)

But $\log 57.8235=$ RunonHealth

Thus,

The impact of a run-on health (iRunonHealth) on remittances and financial inclusion is given by the equation;

iRunonHealth $=108.092-19.275 *$ Remittances $-16.389 *$ FinancialInclusion (8)

The negative sign (-) in the coefficients of Remittances and Financial Inclusion, it indicates that a run-on health (health crisis) negatively impacts financial remittances and financial inclusion at the level of banks and financial institutions. This means that a prolonged health crisis will reduce financial flows and financial inclusion; thus, keeping remittances and financial inclusion levels low in periods of health crisis. On the other hand, an end or reduction or improvement in a health crisis would rejuvenate financial remittances and financial inclusion at the level of banks. This action would gradually cause remittances and financial inclusion to rise back to their original levels before the crisis began, assuming all other factors are constant. But the coefficients of the independent variables (remittance and financial inclusion) are not statistically significant with respective Wald chi-square of .000 and .000 , and corresponding significance p-value of .996 and .996 , with both being greater than the critical p-value of 0.05 . This means that those coefficients (-19.275 and -16.389) are as good as 0 (zero) in interpreting the results. In essence, the equation iRunonHealth $=108.092$ $19.275 *$ Remittances $-16.389 *$ FinancialInclusion is not statistically significant and does not certainly exist in reality, but only a theoretical construct of a possible relationship between the impact of a health crisis on financial remittances and financial inclusion at the level of financial institutions.

The variables' (remittances and financial inclusion) odd ratios are statistically significant at a $95 \%$ confidence interval (C.I). Though the independent variables' odd ratios are statistically significant, their exponential scores are 0.000 and 0.000 , respectively. This implies that considering all other factors are held constant, an increase or decrease in the level of remittances and financial inclusion by one unit would not signify a weakening or severity in the health crisis. Thus, policymakers should be driven to manage to avert or put an end to a health crisis based on the effects of a health crisis on humans being lifestyle of; hindrance on peaceful living together, social cohesion, physical, mental, economic, social welfare, and psychological wellbeing and to promote a stable environment and economy. Of course, in a 
stable and healthy environment, businesses are sure to flourish, and this could mean a lot to financial flows and inclusion, but cautiously speaking, businessdriven motives (measured in terms of remittances and financial inclusion) to overhaul a crisis look challenging. This is because a crisis by nature is uncertain, and in an uncertain market, people would be trying to take situational advantage. In such a situation, only the smart wins, and anyone can outsmart the king winner because market discipline and ethical deals monitoring, control, and reporting are challenging. This is confirmed by the value of the constant term which ironically refers to the run-on health variable with an exponential score of $8.783 \mathrm{E}+046$, indicating that severe run-on health will spark uncertainty in the levels of remittances and financial inclusion; thus, affecting them exponentially negatively. The full output of the logistic regression analysis is shown in the appendix section.

Table 10: Variables in the Equation of the Direct Effect Results

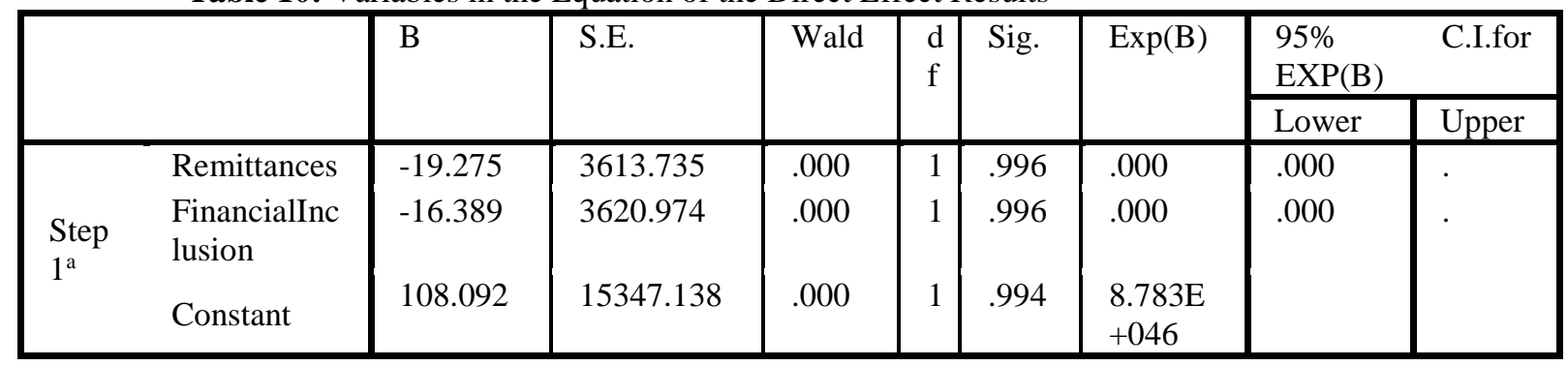

a. Variable(s) entered on step 1: Remittances, FinancialInclusion.

\subsubsection{The Indirect Effect Results}

The indirect effect between the independent variables was assessed using a correlation coefficient technique and the result obtained is displayed in a correlation matrix in table 11. Correlation scores run from -1 to 1 through 0 , with -1 indicating a perfectly negative linear correlation between two variables, 0 indicates no linear correlation between two variables and 1 indicates a perfect positive linear correlation between two variables. Table 11 shows the correlation between variables in the equation; $\mathrm{ARH}=\mathrm{RT}(\mathrm{FI})$; with ARH (a run-on health as the constant term). The results show that;

i. Remittances are negatively affected by a run-on health with a correlation coefficient score of -.706 between remittances and the constant term.

ii. Financial inclusion is negatively affected by a run-on health with a correlation coefficient score of -.708 between remittances and the constant term.

iii. The magnitude of the impact of health run-on remittance (-.706) and on financial inclusion (-.708) is strong and relatively almost the same for remittances and financial inclusion. 
iv. Remittances and Financial inclusion are not linearly correlated with each other during a run-on health. This is evident by the correlation coefficient score of .000 between the two variables. Thus, the hypothesis that under a health-run, the level of remittance is dependent on the level of financial inclusion is rejected.

Table 11: Correlation Matrix Showing the Indirect Effect Results

\begin{tabular}{|ll|l|l|l|}
\hline & & Constant & Remittances & FinancialInclusion \\
\hline \multirow{3}{*}{ Step 1 } & Constant & 1.000 & -.706 & -.708 \\
& Remittances & -.706 & 1.000 & .000 \\
& FinancialInclusion & -.708 & .000 & 1.000 \\
\hline
\end{tabular}

\section{Discussion of Results}

The $71.7 \%$ of respondents with affirmation on the run-on health to be viewed as a health crisis exceeded the probability of obtaining the chi-square statistics $(67.030 \%)$ which is significant in the omnibus tests of model coefficients. This further reaffirms the prevalence of a health crisis. And since the crisis was first reported in China before spreading to other parts of the world, it is obvious that the WHO could be right to have termedinate the crisis a global health crisis or pandemic, since the health crisis has exceeded territorial boundaries and spread within many nations.

Considering that the magnitude of the impact of the health crisis could be strong on remittances and financial inclusion, coupled with the fact that during a health crisis, remittance volume does not dependent on financial inclusion, financial and monetary policymakers would need to relax and cautiously apply appropriate measures that would smoothen financial flows and financial inclusion to stabilise the banking system during the period of health, environmental and economic shocks. The general tendency is that during global uncertainty and shocks, businesses would try to be conservative in their spending, thus reducing the possibility of boosting financial remittances. On the other hand, with no spending-driven motives, coupled with market uncertainty, businesses would have justified reasons to be financially exclusive. Meanwhile, attributing a rise or a fall in the level of remittances and financial inclusion to a health crisis is subjective.

In this scenario, the monetary and financial policy could help reduce the effect. A prudential relaxation can serve as a useful balance to a monetary policy response. It can enhance the ability of monetary policy to support economic activity in a manner that is consistent within its mandate, by removing regulatory constraints that may otherwise impede financial transmission and inclusion. In countries that need to tighten monetary policy (e.g., to limit the inflationary effects of an exchange rate depreciation), a 
simultaneous relaxation of prudential policy can help reduce potential stresses from the domestic tightening of capital flows.

In a resurgence crisis, temporary use of Capital Flow Management Measures (CFMMs) can help prevent a free fall of the exchange rate and provide conscious space while necessary policy adjustments are employed (Harjes et al, n.d.). Mitigating exchange rate burdens and giving central banks more scope to ease or tighten less policy can enhance monetary policy effectiveness which is ineffective during a crisis. Where capital inflows are restricted, their careful relaxation can mitigate net outflow obligations requiring liberalization approval to be ascertained. CFMMs cannot substitute for or avoid warranted adjustment. CFMMs on outflows should generally be broad-based to be effective, and they may require restrictions on some remittance types. According to Nso (2018), the use of technology to perform electronic payments, operations and transactions can help bypass restrictions. Restrictions should be transparently implanted, implemented, and lifted once crisis conditions improve. In handling restrictions, preferential treatment and guidelines could be given to those that do not discriminate on financial remittance placements and financial inclusiveness. A soft requirement would be to close discriminatory restrictions to promote ethically disciplined market environments and provide equal opportunities for all participants in the market.

\section{Conclusion}

The non-interdependence between remittances and financial inclusion during a health crisis suggests that financial authorities and policymakers might have to by-pass tough challenges to influence the level of remittances. Implementing an aggressive financial inclusion policy during a global health pandemic and a conservative and relaxed monetary policy that stabilises remittances at the level of the banking systems would help reduce the magnitude of the impact of a health crisis on businesses. Through proactive and passive actions, any potential impact of a health crisis on remittances and financial inclusion is greatly reduced and progressively ended. This study is limited in that it should have made use of real secondary data on remittance numbers, volumes, and financial inclusion numbers collected from banks or financial institutions during the period of the pandemic.

\section{References:}

1. Agresti, A. (1996). An Introduction to Categorical Data Analysis. NY: Wiley \& Sons

2. Antohi, V., \& Cojocaru, G. (2015). Durable Financing of the Romanian Healthcare System within the European Background. European Scientific Journal, ESJ, 11(22). 
3. Bech, M. L., Gambacorta, L., \& Kharroubi, E. (2012). Monetary policy in a downturn: Are financial crises special? BIS, Working Papers. No 388. September 2012. ISSN 1020-0959 (print), ISSN 16827678(online). Retrieved from: https://www.bis.org/publ/work388.pdf.

4. Bentler, P. (1990). Comparative Fit Indices in Structural Models Permalink. Psychological Bulletin, 107(2), 238-246.

5. Burns, R. P. \& Burns, R. (2008). Business research methods \& statistics using SPSS. SAGE Publications

6. Byrne, B. M. (2013). Structural Equation Modelling with AMOS: Basic Concepts, Applications, and Programming, Second Edition $\left(2^{\text {nd }}\right.$ ed.). Taylor \& Francis. Retrieved from: https://books.google.co.id/books?id=1dHbAAAAQBAJ

7. Carmines, E. G. \& Zeller, R. A. (1979). Reliability and Validity Assessment. Sage Publications, Inc. Retrieved from https://books.google.co.id/books?id=BN_MMD9BHogC

8. Cox, D. R., \& Snell, E. J. (1989). The Analysis of Binary Data, $2^{\text {nd }}$ ed. London: Chapman and Hall

9. Cronbach, L. J. (1951). Coefficient alpha and the internal structure of tests. Psychometrika, 16(3), 297-334, https://doi.org/10.1007/BF02310555

10. Demirguc-Kunt, A., Honophan, P., Beck, T. (2008). Finance for All: Policies and Pitfalls in Expanding Access. World Bank. Washington, DC. Retrieved from: https://openknowledge.worldbank.org/handle/10986/6905

11. Ficawoyi, D. A., Gyan, P., \& Hem, C. B. (2020) Remittance inflows and financial development: evidence from the top recipient countries in Sub-Saharan Africa, Applied Economics, 52:53, 5807-5820, DOI:10.1080/00036846.2020.1776834

12. Field, A. (2013). Discovering statistics using IBM SPSS statistics (4th ed.). Los Angeles, CA: Sage Publications

13. George, D., and Mallery, P. (2003). SPSS for Windows step by step: A simple guide and reference. 11.0 update $\left(4^{\text {th }}\right.$ ed.). Boston: Allyn \& Bacon

14. Hosmer Jr, D. W., Lemeshow, S., and Sturdivant, R. X. (2013). Applied Logistic Regression. Third Edition ( $3^{\text {rd }}$ ed.). Hoboken, New Jersey: John Wiley \& Sons, Inc. Print ISBN: 9780470582473 Online ISBN: 9781118548387. DOI:10.1002/9781118548387

15. Hulland, J. (1999). Use of Partial Least Squares (PLS) in Strategic Management Research: A Review of Four Recent Studies. Strategic Management Journal. 20(4), 195-204. https://doi.org/10.2307/2347739 
16. Johnson, O. E. G. (2020). Financial Sector Development in African Countries, Major Policy Making Issues. Gewerbestrasse: Palgrave Macmillan. 11,6330 Cham, Switzerland AG. ISBN 978-3-030-329372 ISBN 978-3-030-32938-9 (eBook) https://doi.org/10.1007/978-3030-32938-9

17. Leblanc, M., \& Fitzgerald, S. (2000). Logistic regression for school psychologists. School Psychology Quarterly, 15(3), 344-358. https://doi.org/10.1037/h0088791

18. Nagelkerke, N. J. D. (1991). A note on the general definition of the coefficient of determination. Biometrika, 78(3), 691-692

19. Nashipu, T., Dobdinga, C. F. \& Molem, C. S. (2020). Financial Inclusion, Community Capacity Building and Pro-Conservation Behavior around the Northern Periphery of Dja Biosphere Reserve, Cameroon. Journal of Socioeconomics and Development. 3(1), 47-62. DOI: $10.31328 /$ jsed.v3i.1323

20. Nso, M. A. (2018). Impact of Technology on E-Banking; Cameroon Perspectives. International. Journal of Advanced Networking and Applications. 9 (6). 3645-3653

21. Nso, M. A. (2019). SMEs Access to Finance and the Modern Financial Industry. Doctorate in Management Studies specialization in Banking Management Thesis submitted to Indian School of Business Management and Administration

22. Thomas Harjes, David Hofman, Erlend Nier, and Thorvardur Olafsson. (n.d.). Monetary and Financial Policy Responses for Emerging Market and Developing Economies. IMF Monetary and Capital Markets Division. Retrieved from: file:///C:/Users/HP/Downloads/enspecial-series-on-covid19monetaryand-financial-policy-responses-for-emerging-market-anddevelopin.pdf

23. Thompson, Laura (2014). Financial remittances - a tool for development? UNA-UK. Retrieved from: iom.int/oped/financial remittances-tool-development

24. UCLA - Institute for Digital Research and Education Statistical Consulting. (2021). Logistic Regression SPSS Annotated Output. Retrieved from: https://stats.idre.ucla.edu/spss/output/logisticregression/ 


\section{Appendix: Output of Logistic Regression \\ Logistic Regression \\ Case Processing Summary}

\begin{tabular}{|c|c|c|}
\hline Unweighted Cases $^{\mathrm{a}}$ & $\mathrm{N}$ & Percent \\
\hline Included in Analysis & 60 & 100.0 \\
\hline Selected Cases & 0 & .0 \\
\hline Total & 60 & 100.0 \\
\hline Unselected Cases & 0 & .0 \\
\hline Total & 60 & 100.0 \\
\hline
\end{tabular}

a. If weight is in effect, see the classification table for the total number of cases.

Dependent Variable Encoding

\begin{tabular}{|c|c|}
\hline $\begin{array}{c}\text { Original } \\
\text { Value }\end{array}$ & $\begin{array}{c}\text { Internal } \\
\text { Value }\end{array}$ \\
\hline Yes & 0 \\
No & 1 \\
\hline
\end{tabular}

Block 0: Beginning Block

Classification Table ${ }^{\mathrm{a}, \mathrm{b}}$

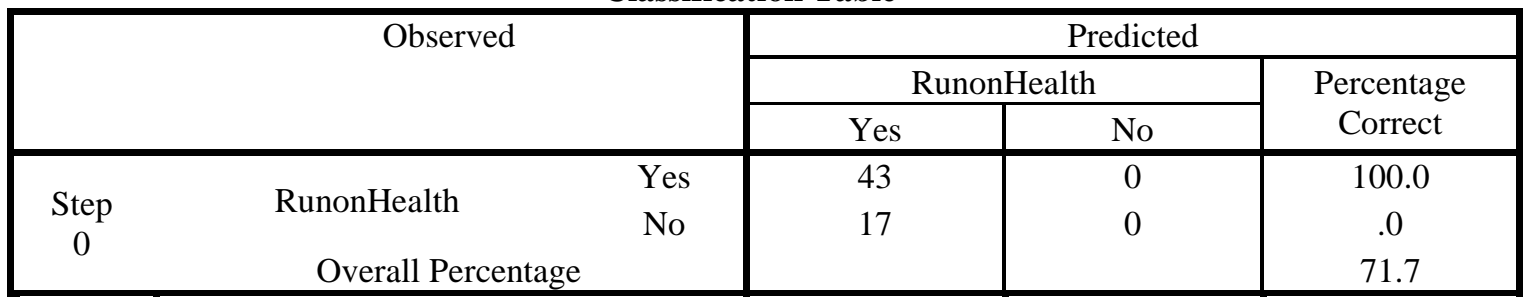

a. Constant is included in the model.

b. The cut value is .500

Variables in the Equation

\begin{tabular}{|cc|c|c|c|c|c|c|}
\hline & & B & S.E. & Wald & df & Sig. & Exp(B) \\
\hline $\begin{array}{cc}\text { Step } \\
0\end{array}$ & Constant & -.928 & .286 & 10.492 & 1 & .001 & .395 \\
\hline
\end{tabular}

Variables not in the Equation

\begin{tabular}{|c|c|c|c|}
\hline & Score & df & Sig. \\
\hline Remittances & 44.248 & 1 & .000 \\
\hline
\end{tabular}




\begin{tabular}{|ccc|c|c|c|}
\hline $\begin{array}{c}\text { Step } \\
0\end{array}$ & $\begin{array}{c}\text { Variable } \\
\mathrm{S}\end{array}$ & FinancialInclusion & 43.650 & 1 & .000 \\
& \multicolumn{2}{c|}{ Overall Statistics } & 45.358 & 2 & .000 \\
\hline
\end{tabular}

Block 1: Method = Enter

Omnibus Tests of Model Coefficients

\begin{tabular}{|cc|c|c|c|}
\hline & & Chi-square & df & Sig. \\
\hline & Step & 67.030 & 2 & .000 \\
Step & $\begin{array}{c}\text { Bloc } \\
\text { k } \\
1\end{array}$ & 67.030 & 2 & .000 \\
& $\begin{array}{c}\text { Mod } \\
\text { el }\end{array}$ & 67.030 & 2 & .000 \\
\hline
\end{tabular}

Model Summary

\begin{tabular}{|c|c|c|c|}
\hline Step & $\begin{array}{c}-2 \text { Log } \\
\text { likelihood }\end{array}$ & $\begin{array}{c}\text { Cox \& Snell } \\
\text { R Square }\end{array}$ & $\begin{array}{c}\text { Nagelkerke R } \\
\text { Square }\end{array}$ \\
\hline 1 & $4.499^{\mathrm{a}}$ & .673 & .966 \\
\hline
\end{tabular}

a. Estimation terminated at iteration number 20 because maximum iterations has been reached. Final solution cannot be found.

Hosmer and Lemeshow Test

\begin{tabular}{|c|c|c|c|}
\hline Step & Chi-square & df & Sig. \\
\hline 1 & .000 & 5 & 1.000 \\
\hline
\end{tabular}

Contingency Table for Hosmer and Lemeshow Test

\begin{tabular}{|cc|c|c|c|c|c|}
\hline & & \multicolumn{2}{|c|}{ RunonHealth = Yes } & \multicolumn{2}{c|}{ RunonHealth = No } & \multirow{2}{*}{ Total } \\
\cline { 2 - 6 } & Observed & Expected & Observed & Expected & \\
\hline \multirow{4}{*}{ Step } & 1 & 8 & 8.000 & 0 & .000 & 8 \\
1 & 2 & 2 & 2.000 & 0 & .000 & 2 \\
& 3 & 26 & 26.000 & 0 & .000 & 26 \\
& 5 & 6 & 6.000 & 0 & .000 & 6 \\
& 6 & 1 & 1.000 & 6 & 6.000 & 7 \\
& 7 & 0 & .000 & 3 & 3.000 & 3 \\
& 0 & .000 & 8 & 8.000 & 8 \\
\hline
\end{tabular}




\section{Classification Table ${ }^{\mathrm{a}}$}

\begin{tabular}{|c|c|c|c|c|c|}
\hline & \multirow{3}{*}{\multicolumn{2}{|c|}{ Observed }} & \multicolumn{3}{|c|}{ Predicted } \\
\hline & & & \multicolumn{2}{|c|}{ RunonHealth } & \multirow{2}{*}{$\begin{array}{c}\text { Percentage } \\
\text { Correct }\end{array}$} \\
\hline & & & Yes & No & \\
\hline $\begin{array}{c}\text { Step } \\
1\end{array}$ & $\begin{array}{r}\text { RunonHealth } \\
\text { Overall Pe }\end{array}$ & $\begin{array}{l}\text { Yes } \\
\text { No }\end{array}$ & $\begin{array}{c}42 \\
0\end{array}$ & $\begin{array}{c}1 \\
17\end{array}$ & $\begin{array}{c}97.7 \\
100.0 \\
98.3\end{array}$ \\
\hline
\end{tabular}

a. The cut value is .500

Table 12: Variables in the Equation

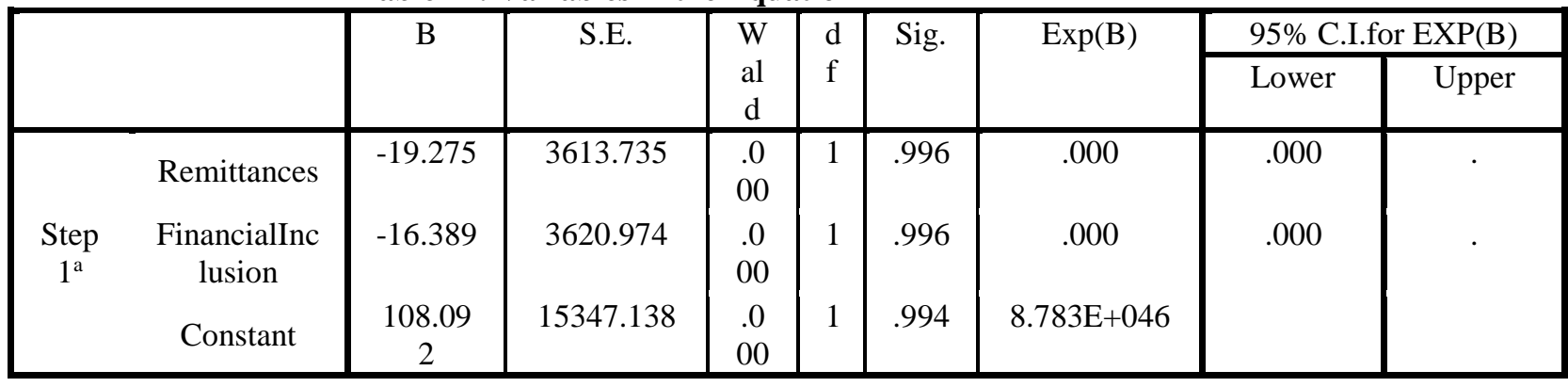

a. Variable(s) entered on step 1: Remittances, FinancialInclusion.

\section{Correlation Matrix}

\begin{tabular}{|c|c|c|c|c|}
\hline & & Constant & Remittances & $\begin{array}{l}\text { FinancialInclus } \\
\text { ion }\end{array}$ \\
\hline Step 1 & $\begin{array}{l}\text { Constant } \\
\text { Remittances } \\
\text { FinancialInclusion }\end{array}$ & $\begin{array}{l}1.000 \\
-.706 \\
-.708\end{array}$ & $\begin{array}{l}-.706 \\
1.000 \\
.000\end{array}$ & $\begin{array}{l}-.708 \\
.000 \\
1.000\end{array}$ \\
\hline
\end{tabular}

End. 